\title{
PERKEMBANGAN MUSIK HIP-HOP SEBAGAI PRODUK BUDAYA POPULAR AMERICAN MUSIC AND RADIO MUSIC, RACE, AND CULTURE
}

\author{
Merrisa Octora
}

\begin{abstract}
This research describes about the growth of popular culture with one relevant example of popular culture product called music but with the specific mainstream called Hip-Hop. This era is also well known with the era of technology and the spread worldwide quickly rather than we thought. Advances in technology now moves so quickly that directly affect the lives of people in the world, for example with new innovations with all the advantages that make it as a product that is consumed and even become a role model gadget by the society such as iPod, Music, Internet, Hollywood Movies, Jeans, BlackBerry, iPhone, Music, Barbie, etc. America is a highest standard for these products then the power of mass media distribute through advertisements, songs, movies, internet, cable tv and deploy these products to the world and then consumed by society who later became part of our daily lives . These products are known as popular culture. One way to find out is the study of popular culture is through music. The music certainly can not be separated from popular culture because it is a culture that has a lot of fans around the world virtually. In this paper the author tried to theme music Hip-Hop as the study of popular culture products.
\end{abstract}

Key words : popular culture, music, hip-hop, worldwide, technology

\section{PENDAHULUAN}

Kemajuan teknologi sekarang ini bergerak dengan sangat cepat sehingga secara langsung mempengaruhi kehidupan masyarakat didunia misalnya dengan inovasi-inovasi baru dengan segala kelebihannya yang menjadikannya sebagai suatu produk yang dikonsumsi dan bahkan menjadi gadget yang menjadi panutan oleh masyarakat luas seperti $\mathrm{Mp3}$, Internet, Hollywood Movies, Jeans, BlackBerry"s gadget,iPhone, iPod, iPad, Music, Barbie, dll. Amerika merupakan kiblat bagi produk-produk ini yang kemudian dengan kekuatan media massanya baik melalui iklan, lagu, film, internet, tv cable lalu menyebarkan produk-produk ini ke penjuru dunia dan kemudian dikonsumsi oleh masyarakat yang kemudian menjadi bagian dari kehidupan kita sehari-hari. Produk ini dikenal sebagai popular culture.

Berbicara tentang popular culture adalah sesuatu tidak bisa di pisahkan dengan suatu produk yang di sukai dan di gemari oleh banyak orang. Secara tidak langsung popular culture ini juga mempengaruhi kehidupan kita sehari-hari sebagai contoh popular culture mempengaruhi cara kita berpakaian, apa yang kita makan, dan bahkan apa yang kita pikirkan tentang diri kita sendiri. Namun kita perlu mengetahui lebih dulu apa yang di maksud dengan popular culture. Sangat sulit untuk mendefinisikan apa yang dimaksud dengan budaya popular karena karena kajian budaya popular ini berhubungan dengan berbagai macam disiplin ilmu (interdiscipiliner). Budaya secara umum adalah suatu proses perkembangan intelektual, spiritual dan estetika. ${ }^{1}$ Pemahaman budaya juga didefinisikan sebagai cara atau

jalan hidup seperti yang dijelaskan oleh Mukerji dan Schudson dalam Rethinking Popular Culture "...from the omnibus definition of culture as a people"s "way of life" and toward a view of culture as a people"s shared mental categories and contents, the governing "rules" that order perception, thought and action."(p. 20) Sedangkan popular adalah sesuatu hal yang sedang berkembang di masyarakat secara luas dan menjadi kecintaan suatu masyarakat. Jadi

\footnotetext{
${ }^{1}$ Storey, Teori Budaya dan Budaya Pop. Memetakan Lanskap Konseptual Cultural Studies, 2004:3
} 
dapat disimpulkan bahwa budaya popular adalah budaya yang disenangi dan disukai oleh masyarakat secara umum"2 Whetmore juga menambahkan bahwa

"Popular culture represents a common denominator, something that cuts across most economic. Social, and educational barriers". "If the notion of culture reflects a certain degree of social stratification and differentiation, then popular culture represents the elements of everyday life, the artifacts, and institution shared by a society, and a body of common knowledge"3

Jadi dapat disimpulkan bahwa budaya popular adalah budaya masyarakat yang terdiri dari unsur-unsur kebudayaan yang tersebar luas di semua lapisan masyarakat yang merupakan refleksi dari suatu masyarakat dan mampu mempengaruhi kehidupan suatu masyarakat dan juga suatu kebudayaan yang kemudian menjadikan masyarakatnya sebagai target utama pemasaran produk budayanya. Berbicara tentang kebudayaan popular tidak bisa dilepaskan dari kebudayaan tinggi (high culture) yang kemunculannya jauh sebelum budaya popular ada. Budaya tinggi merupakan budaya golongan kelas atas yang hanya dapat dinikmati oleh masyarakat golongan tertentu. Beberapa perbedaan yang dapat dijabarkan adalah sebagai berikut, budaya popular merupakan budaya yang dapat dinikmati oleh semua lapisan masyarakat dan bertujuan untuk kesenangan dan lebih mementingkan kuantitas karena diproduksi secara massa dimana produk budaya popular ini memerlukan media sebagai sarana publikasi secara besar-besaran dan uang merupakan instrument terbesarnya (capital). Seperti proses yang dijelaskan oleh Hirsch dalam Processing Fads and Fashion An Organization-Set Analysis of Cultural Industry System "In modern, industrial societies, the production and distribution of both fine art and popular culture entail relationship among a complex network of organizations which both facilitate and regulate the innovation process. Each object must be "discovered," sponsored, and brought to the public attention by entrepreneurial organizations or nonprofit agencies before the originating artist or writer can be linked successfully to the intended audience...". The content of a nation "s popular culture is especially subject to economic constraints due to the larger scale of capital investment required in this area to link creators and consumers effectively". (Rethinking Popular Culture Contemporary Perspectives in Cultural Studies, 1991, 314)

Budaya populer memiliki kecenderungan untuk mengikuti trend yang ada di masyarakat sedangkan budaya tinggi adalah kebudayaan yang hanya dapat diterima oleh golongan masyarakat tertentu dan lebih mementingkan kualitas, tidak memerlukan media publikasi karena sudah memiliki pangsa pasar tersendiri dan tidak memiliki kecenderungan untuk mengikuti perkembangan yang ada di dalam masyarakat (mainstream) karena sudah memiliki karakter tersendiri.

Budaya popular adalah salah satu aspek penting dalam kehidupan karena budaya popular adalah cerminan dari kehidupan masyarakat disekitar kita sehingga bisa membantu kita dalam mempelajari tentang suatu kehidupan masyarakat tertentu. Mukerji dan Schudson menerangkan "Popular culture refers to the beliefs and practices and the object through which they are organized that are widely shared among a population. This includes folk beliefs, practices and objects rooted in local traditions and mass beliefs, practices and objects generates in political and commercial centers. "4

Salah satu cara untuk mengetahui kajian budaya popular adalah melalui musik. Musik sudah pasti tidak bisa dipisahkan dari kebudayaan popular karena merupakan suatu kebudayaan yang memiliki banyak penggemar hampir diseluruh dunia. Dalam tulisan ini

\footnotetext{
${ }^{2}$ Imanto, Budaya Populer dan Realitas Media, http://www.esaunggul.ac.id/article/budaya-populer-dan-realitasmedia/

${ }^{3}$ Common Culture Reading and Writing about American Popular Culture. Michael Petracca and Madeleine Sorapure, P. 3-4

${ }^{4}$ Rethingking Popular Culture. Contemporary Perspective in Cultural Studies, 1991.
} 
penulis mencoba untuk mengusung tema musik Hip-Hop sebagai kajian produk budaya populer.

\section{PERKEMBANGAN MUSIK HIP-HOP}

Seperti produk budaya popular lainnya, Musik juga membawa dampak yang sangat bagi perkembangan musik diseluruh dunia dan dapat dikatakan sebagai refleksi keadaan sosial dari masyarakat tertentu karena musik adalah bagian dari kebudayaan atau dengan kata lain musik adalah perwujudan dari kebudayaan. Salah satu contohnya adalah musik hiphop yang identik dengan musik komunitas Black yang memang original berasal dari musik kebudayaan African America. Musik Hip-Hop juga dikenal sebagai musik Rap.

Hal ini disebabkan oleh musik hip hop berkembang di komunitas African America yang memiliki pengaruh dari kebudayaan Afrika kuno yaitu kebudayaan yang berupa tradisi cerita yang dikisahkan dari mulut ke mulut (lisan) secara turun menurun yang juga mendapat pengaruh dari budaya Jamaica dan lainnya.

"The origins of rap are various, all coming from oral traditions: the African griots, the "talk over" or "spoken words" of the Jamaican culture and the blues and gospel as artistic and verbal ways for the Black to denounce their condition." Then "It"s a form of expression that finds its root imbedded deep within ancient African culture and oral traditional".

Jadi sama halnya dengan musik rock yang merupakan ekspresi dari pemberontakan orang muda dari kekangan orang tua dan guru seperti yang diungkapkan oleh De Mott "For youngsters, too, it may be added, there is value in an escape from the narrow worlds of schoolhouse or family dining room into a sense of power physicality, roughness, openness." 6 Musik hip-hop juga merupakan juga ekspresi dari komunitas African America yang merasa tertekan akan kehidupan pada masa itu yang juga diungkapkan oleh Muhni

"People"s traditional music and the way people"s behave when performing it are symbolic expression of broad cultural pattern and social organization" kemudian lebih lanjut beliau menyatakan "when the Blacks dream of prosperity and becoming rich landowners fall out, they move to the cities dreaming of yet another success: but again, they are disillusioned in the cities their lives get worse. It is difficult to find job and they live in the slums." 7

Musik hip-hop ini lalu berkembang menjadi satu kebudayaan dari masyarakat African America yang pada awalnya mereka tinggal di daerah agrarian yang masih sangat miskin sehingga kemudian mereka berpindah ke kota dengan tujuan untuk mendapatkan kehidupan yang mungkin lebih baik dengan mendapatkan pekerjaan namun pada kenyataannya mereka menghadapi masalah yang sama peliknya. Hal ini ditambah dengan pukulan perekonomian Amerika ketika mengalami deindustrialisasi. Sumber perekonomian global yang semula di kelola oleh bisnis lokal dan perusahaan nasional kemudian berpindah ke perusahaan internasional. Perusahaan-perusahaan berkapasitas internasional ini mendapatkan kekuasaannya di dalam pasar, pabrik-pabrik bergerak pindah dari kota ke daerah yang memiliki tenaga kerja murah. Hasilnya banyak orang Amerika yang memiliki kemampuan teknis dan tingkat pendidikan yang kurang menerima bayaran yang rendah dalam sektor jasa dan seiring dengan waktu ada golongan yang semakin sejahtera dan yang semakin miskin yang menimbulkan kesenjangan sosial. Golongan bawah ini kebanyakan berasal komunitas Black dan Hispanik dengan tingkat gaji yang rendah, pengangguran, peningkatan tindakan kriminal yang sering dihubungkan dengan penggunaan obat terlarang hal ini merupakan

5 http//wwww icce rug nl/soundscapes/DATABASES/MIE/Part2_chapter08.shmtl

${ }^{6}$ Benjamin DeMott. Rock As Salvation. New York Times Magazines, August 25, 1968.

\footnotetext{
${ }^{7}$ Djurhertati Imam Muhni, Early Downhome Blues In American Culture. Humaniora Volume XII. No. 2/2000.
} 
akibat dari deindustrialisasi di Amerika. Terlebih lagi banyak di antara masyarakat ini yang menderita sakit karena efek samping dari pembaharuan kota sebagai contoh penggusuran pemukiman rumah untuk di jadikan jalan tol.

Daerah yang mengalami pukulan keras dari deindustrialisasi dan pembaharuan kota ini adalah South Bronx, New York dan aliran musik hip hop muncul di daerah ini untuk pertama kalinya pada awal tahun 1970an sebagai bentuk perlawanan dari semua bentuk tekanan dari kondisi yang ada. Hip-Hop muncul sebagai akibat tekanan dari postindustri dan ekspresi dari komunitas Black ini. ${ }^{8}$

Musik aliran Hip-Hop ini memiliki beberapa elemen dasar yaitu tarian Hip-Hop seperti breakdance dan street dance kemudian seni graffiti lalu Djing serta Rapping dan juga Hip-Hop fashion seperti bling-bling styles dan baggy pants. Dalam perkembangannya Hip- Hop menjadi sangat mewabah dimana-mana tidak hanya disukai oleh komunitas Black saja tetapi juga dari White tetapi hal itu merupakan proses yang sangat panjang karena masih adanya diskriminasi rasial yang melekat dan mengidentikkan bahwa musik Hip-Hop adalah musik komunitas Black seperti yang diilustrasikan oleh Samuels sebagai berikut

"The moral inversion of racist stereotypes as entertainment has lost whatever transformative power it may arguably have had fifty years ago. Mc search of 3rd Bass, a white rap traditionalists, with short-cropped hair and thick-rimmed Buddy Holly glasses, formed his style in the uptown hip-hop clubs like the L.Q. in the early 1980s. "Ten or eleven years ago," he remarks, "when I was wearing my permanent-press Lee"s with a beige campus shirt and matching Adidas sneakers, Kids I went to school with were calling me a „, wigger, " „blackwanna-be, "all kinds ofracistnames. ”9

Namun seiring dengan perkembangan waktu musik Hip-Hop tidak lagi dinikmati oleh golongan kulit hitam saja tetapi mulai mewabah ke kaum kulit putih terutama anak mudanya memang dari awalnya ada golongan kulit putih yang menyukai musik hip-hop ini tapi seperti yang disebut masih dihalangi dengan stereotypes musik hip-hop adalah musik black dan sekarang ini musik Hip-Hop menjadi suatu trendsetter bagi penggemar musik di Amerika. Perjalanan musik Hip-Hop sama seperti musik Blues yang dulunya dianggap aneh dan merupakan ciri khas Black namun sekarang menjadi suatu hiburan yang menjanjikan seperti yang diungkapkan oleh Muhni "Though blues is first described as weird, dismall, doleful, and course by whites later it is accepted as a wonderful entertaintment. "10 Begitu juga dengan musik Hip-Hop sekarang menjadi suatu trendsetter dan wonderful entertainment di Amerika dan dunia. Bukti bahwa musik Hip-Hop menjadi suatu entertainment yang menyenangkan dan menjadi trendsetter adalah dengan kesmpatan yang didapat oleh bintang-bintang Hip-Hop untuk tampil bisa di acara bergengsi seperti "Saturday Night Live" contohnya adalah Lauryn Hill dengan penjualan albumnya The Miseducation of Lauryn Hill yang berhasil meraih 10 nominasi penghargaan Grammy. Musik Hip-Hop yang dulunya tidak bisa diterima namun sekarang menjadi gaya hidup yang tidak bisa dilepaskan dari kehidupan anak muda Amerika. Lebih lanjut Samuels menjelaskan "Now those same kids are driving Jeeps with MCM leather interiors and pumping Public Enemy." Tidak hanya di Amerika dan dikonsumsi oleh kulit hitam saja tetapi juga dikonsumsi oleh whites dan juga musik hip-hop menyebar hampir keseluruh dunia seperti Asia, Eropa, dan kawasan lainnya hal ini dikarenakan musik Hip-Hop dipandang sebagai suatu trend yang merupakan produk budaya popular Amerika yang kemudian mewabah dan dikonsumsi hampir diseluruh dunia dan salah satu factor mengapa musik Hip-Hop menjadi trendsetter di Amerika adalah melalui radio ada banyak stasiun yang

\footnotetext{
${ }^{8}$ America ${ }^{e e}$ s Musical Life A History

${ }^{9}$ David Samuels. The Rap on Rap. The New Republic, Nov. 11,1991

${ }^{10}$ Early DownHome Blues In American Culture.
} 
terdapat di Amerika dan hal ini dikarenakan adanya kecenderungan orang Amerika untuk mendengarkan radio dibandingkan menonton TV pada waktu-waktu tertentu dan dari radio ini mereka bisa mendengarkan lagu-lagu Hip-Hop dengan format stasiun radio yang berbeda ada alasan kuat mengapa orang-orang lebih suka mendengarkan radio karena radio menawarkan sesuatu yang mereka ingin dengarkan yang tidak bisa mereka dapatkan ditempat lain.”"11

Kemudian setelah mereka mendengarkan aliran musik Hip-Hop ini mereka kemudian membeli CD atau kasetnya tidak hanya oleh black tetapi juga whites dan group etnis lainnya seperti yang kepada jelaskan oleh August. Et al "Hip-Hop got its start in black America, but now more than $70 \%$ of hip-hop albums are purchased by whites. In fact, a whole generation of kids-black, white, Latino, Asian-has grown up immersed in hip-hop."12 Secara umum musik hip-hop adalah musik yang mengusung tema sosial seperti kriminalitas, sexual abuse, politic, drugs, kemiskinan, dan lainnya hal ini dikarenakan oleh pengalaman dari komunitas kulit hitam yang kemudian dituangkan kedalam musik sebagai bentuk pelarian dari penderitaan yang menghimpit atau form of escape. Seperti yang dijelaskan oleh Samuels "Most rap performers are black males and the lyric of most outlaw rap deals in harshly explicit language with the sexual, social and legal problems of inner-city black men and adolescent."

Musik Hip-Hop terbentuk dari komunitas African American sebagai ekspresi dari keadaan yang mereka alami pada waktu itu seperti deindustralisasi dan pembaharuan kota (urban renewal). Musik hip hop atau yang bisa juga disebut dengan musik rap adalah jenis aliran musik yang mengutamakan olah suara yang kemudian di padupadankan dengan alat musik seperti mixes.

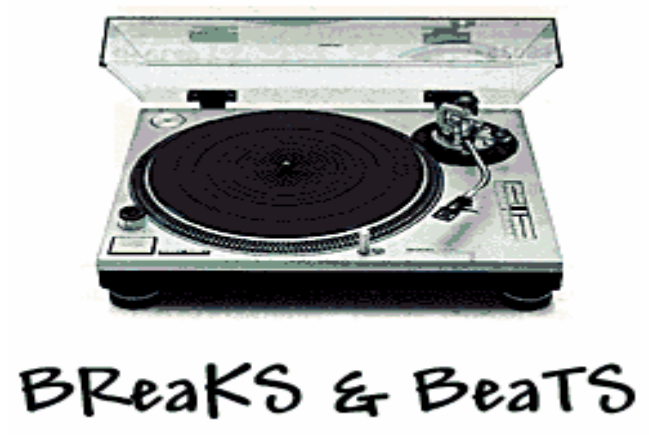

Musik hip hop dikenal dengan istilah gaya bling-bling di mana para penyanyinya menggunakan perhiasan, mobil dan barang-barang bermerek mulai menjadi trend pada akhir tahun 1990an. hal ini sebenarnya bukan sekedar gaya tetapi lebih kepada kompensasi dari tekanan hidup yang di alami oleh komunitas kulit hitam selama ini dan ketika mereka berhasil dalam usahanya mereka merealisasikan apa yang mereka inginkan melalui barang-barang mewah itu. Karena, dengan memiliki mobil mewah, uang, perhiasaan dan pakaian bermerek merupakan symbol dari kekayaan dan status. Jadi penggunaan gaya bling-bling dalam hip hop tidak sekedar menjadi gaya bagi komunitas hip hop kulit hitam tetapi lebih sebagai suatu pencapaian dalam hal materi dan status. Pemakaian baju atau celana yang kebesaran (baggy) sudah di anggap sebagai dari bagian dari musik hip hop tetapi sebenarnya merupakan suatu keadaan di mana ketika mereka tumbuh dewasa mereka tidak harus membeli pakain yang

\footnotetext{
${ }^{11}$ The New Sound of Radio. William H. Honan. New York Times Magazines, December 3, 1967.

${ }^{12}$ Rap and Hip-Hop: A Casebook. Hip-Hop Nation: There ${ }^{\text {ee }}$ More To Rap Than Just Rhythms andRhymes. Melissa August. Et al. Common Culture. P. 300-301.
} 
baru lagi cukup memakai yang sudah ada terutama pada anak-anak di slums "Kids originally wear large baggy pants so they can grow up without having to buy new ones"13

Dalam musik hip hop jika di perhatikan terkadang dalam video klip mereka menggunakan jam berbentuk kalung. Penggunaan kata waktu dalam lagu beraliran hip hop dan penggunaan aksesoris jam adalah suatu tanda yang berfungsi sebagai alat komunikasi verbal antara anggota masyarakat bahwa penggunaan kata waktu dan aksesoris jam merupakan bagian dari gaya Hip-Hop tetapi sebenarnya penggunaan kata waktu dan aksesoris jam dalam komunitas Hip-Hop yang mayoritas adalah black merupakan indikasi bahwa mereka (black community) menginginkan adanya perubahan, untuk menentang kelompok dominan yang menekan kelompok minoritas. Jadi penggunaan aksesoris jam di musik Hip- Hop bukan sekedar bagian dari gaya Hip-Hop tapi memiliki arti lebih yaitu menginginkan adanya perubahan untuk komunitas kulit hitam. Terkadang dalam aliran musik hip hop kita sering mendengar adanya penggunaan sirene polisi, helicopter, suara peluru, gelas pecah yang sebenarnya merupakan suatu penggambaran dari pergerakan kulit hitam pada tahun 1960an yang ditentang oleh mayoritas kulit putih pada waktu itu.

Musik Hip-Hop merupakan salah satu produk budaya popular yang dulunya dianggapnya sebagai musik kulit hitam sekarang menjadi mewabah di Amerika, mempengaruhi perfilman di Hollywood, literature, fashion dan musik Hip-Hop dikonsumsi oleh sebagian besar orang di Amerika bahkan dunia dengan penjualan CD yang mencapai 81 juta keping dan meningkat sebanyak $31 \%$ melebihi penjualan musik popular lainnya seperti pop.

Seperti yang digambarkan oleh August. Et al. "Consider the number. In 1998, for the first time ever, rap outsold what previously had been America"s top selling format, country music. Rap sold out more than 81 millions CDs, tapes and albums last year, compared with 72 million of country. Rap sales increased a stunning 31\% from 1997 to 1998 in contrast to 2\% gains for country, $6 \%$ for rock and 9\% for rock industry overall. Boast rapper Jay-Z, whose current album, Vol. 2... Hard Knock Life (Def jam), has sold more than 3 millions copies.” Musik hip-hop juga telah menjadi salah satu pengaruh terbesar di Amerika baik di perfilman Hollywood dan juga fashion, masih dalam artikel yang sama August. Et al menerangkan "Hiphop is the rebellious voice of the youth. It"s what people want to hear." Even if you are not into rap, hip-hop is all around you. It pulses from the films you watch (Seen a Will Smith movie lately?), the books you read (even Tom Wolfe peels off a few raps in his best-selling new novel), the fashion you wear (Tommy Hilfiger, FUBU)." Hollywood merupakan pusat industri perfilman terbesar di Amerika dan musik Hip-Hop mempengaruhi perfilman Hollywood juga banyak bintang-bintang Hip-Hop turut ambil bagian dalam Film-

Film yang dibuat oleh rumah produksi-produksi terkenal seperti Motion Picture, Paramount, $20^{\text {th }}$ Century, Fox, dll yang memasukkan unsur Hip-Hop didalamnya "Hollywood too is the feeling of the rap beat. After Lauryn Hill passed on a role in the Cider House Rules (an adaptation of John Irving book), filmmakers cast Hip-Hop soul singer Erykah Badu. Ice Cube, who has appeared in such movies as Boyz $N$ the Hood and Fridays, will soon star with George Clooney in the Gulf War thriller Three Kings. Queen Latifah featured in the recent film Living Out Loud, is now set to be the host of a TV talk show. And the former Fresh Prince, Will Smith, has become one of the most in demand actor around. Ice Cube- who

performed a song with Public Enemy titled "Burn Hollywood Burn" in 1990-says Tinseltown wants rapper actors because "we add a sense of realism where sometimes a trained actor can " $t$ deliver that reality the way it needs to be done." 14 Musik Hip-Hop membawa

\footnotetext{
${ }^{13}$ http://www.icce.rug.nl/-soundscapes/DATABASES/MIE/Part2_chapter08.shmtl

${ }^{14}$ Rap and Hip-Hop: A Casebook. Hip-Hop Nation: There ${ }^{e e}$ s More To Rap Than Just Rhythms and Rhymes. Melissa August. Et al. Common Culture. P. 300-301.
} 
perubahan yang berpengaruh dalam aspek seni dan budaya di Amerika, jadi dapat dikatakan bahwa musik Hip-Hop adalah produk budaya popular yang berkaitan dengan selera masyarakat dan juga merupakan refleksi masyarakat yang secara tidak langsung juga merubah kehidupan masyarakat secara luas karena budaya popular yang memiliki sifat dinamis dan terkadang menjadi inisiator perubahan dalam segala aspek. ${ }^{15}$

\section{MUSIK HIP-HOP DAN PERKEMBANGAN DI INDONESIA}

Sebagai salah satu produk budaya popular musik Hip-Hop mewabah hampir diseluruh dunia dan semua gaya dari Hip-Hip dijadikan trendsetter bagi anak-anak muda dewasa ini. Indonesia adalah salah satu contohnya sekarang ini kita melihat banyak anak muda yang menggunakan gaya Hip-Hop mulai dari bling-bling styles, baggy pants, sepatu sneaker, seni graffiti, atau penambahan nama yang memiliki unsur Black People seperti Dj Boim Ghettos. Istilah Ghettos merujuk kepada wilayah dimana kaum minoritas tinggal dan penuh dengan tekanan sosial dan ekonomi dan sedikit mendapatkan pengawasan dari pihak terkait sehingga rawan dengan tindakan kekerasan dan kejahatan. Hal ini dikarenakan musik Hip-Hop bagi mereka adalah suatu trendsetter, karena merupakan produk budaya popular terlebih-lebih musik Hip-Hop itu berasal dari Amerika yang merupakan kiblat bagi pusat fashion dunia, musik, film dan hal lainnya. Gaya Hip-Hop diserap menjadi suatu trendsetter bagi anak muda, tetapi apakah mereka mengerti kenapa gaya itu ada dan menjadi bagian dari Hip-Hop styles. Ada banyak group musik Hip-Hop yang bermunculan di Indonesia misalnya Thoriq and The Juice yang materi lagunya juga mengusung tema sosial seperti masalah pemujaan materi pada anak-anak dikota besar dan gaya hidup hedonisme dikota besar.

\section{KESIMPULAN}

Pop culture adalah suatu kebudayaan yang disukai dan digemari oleh banyak orang. Sehingga terkadang disebut sebagai budaya massa (masyarakat) yang merupakan karakter utama dari budaya popular. Yang termasuk di dalam budaya popular salah satunya adalah musik dan radio. Musik merupakan produk yang disukai Contoh yang diambil disini adalah musik dengan aliran hip hop yang merupakan suatu aliran musik kebebasan yang diakibatkan oleh tekanan yang dihadapi oleh komunitas masyarakat kulit hitam pada saat itu dan juga sebagai bentuk pelarian dari kenyataan hidup atau yang dikenal dengan form of escape. Lagu- lagu beraliran hip hop dan gaya bling-bling tidak sekedar trend melainkan memiliki makna yang lebih dalam lagu yang teksnya cenderung mengusung tema sosial yang mungkin dianggap sebagai trend oleh sebagian orang sebenarnya memiliki makna yang lebih dalam jika kita lihat dari sejarahnya hip hop adalah musik yang merefleksikan keadaan komunitas black pada saat itu dan penggunaan gaya bling-bling bukan hanya sekedar gaya melainkan sebuah kompensasi berdasarkan status dan materi.

Musik hip hop merefleksikan keadaan masyarakat yang juga merupakan salah satu karakteristik dari budaya popular. Jadi bisa ditarik kesimpulan bahwa musik hip-hop adalah salah satu produk dari komunitas kulit hitam di Amerika dan yang kemudian menjadi salah satu produk popular Amerika. Musik Hip-Hop mempengaruhi segala aspek di Amerika baik itu fashion, perfilman, dan lainnya. Amerika sebagai kiblat dunia dengan film, musik, fashion, internet, dll secara tidak langsung menyebarkan musik Hip-Hop sebagai salah satu produk budaya.

\footnotetext{
${ }^{15}$ Common Culture Reading and Writing about American Popular Culture. Michael Petracca and Madeleine Sorapure. P. 4.
} 


\section{BIBLIOGRAPHY}

- DeMott, Benjamin. Rock As Salvation. New York Times Magazines, August 25, 1968.

- Honan, William H. The New Sound of Radio. New York Times Magazines. December 3, 1967.

- Imanto, Teguh. Budaya Populer dan Realitas Media. http://www.esaunggul.ac.id/article/budaya-populer-dan-realitas-media/ 6 Desember 2013

- Mukerji, Chandra and Michael Schudson. Rethingking Popular Culture. Contemporary Perspectives in Cultural Studies. California. University of California Press. 1991.

- Muhni, Djuhertati Imam. Early Downhome Blues In American Culture. Humaniora Volume XII. No. 2/2000.

- Petracca, Michael. And Madeleine Sorapure. Common Culture Reading and Writing about American Popular Culture. New Jersey. Pearson Education, Inc. 2004.

- Samuels, David. The Rap on Rap. The New Republic, November 11, 1991.

- Storey, John. Teori Budaya dan Budaya Pop. Trans. Elli El Fajri. Yogyakarta. Penerbit Qalam. 2004.

- Americaes Musical Life a History

- American Popular Culture Volume III

- http://www.answer.com/topic/music. 1 Desember 2013

- http://www.icce.rug.nl/soundscapes/DATABASES/MIE/Part2_chapter08.shmtl 4 Desember 2013. 